\title{
EXAMINATION OF THE POSSIBILITIES OF THE APPLICATION OF WASTE MATERIALS (GYPSUM, FLY ASH AND BOTTOM ASH) IN CONSTRUCTION
}

\author{
IZUČAVANJE MOGUĆNOSTI PRIMENE OTPADNOG \\ MATERIJALA (GIPSA, PEPELA I ŠLJAKE) U GRAĐEVINARSTVU
}

\author{
Trifunović Prvoslav ${ }^{1}$, Marinković Slobodanka ${ }^{1}$, Kostić-Pulek Aleksandra ${ }^{1}$, \\ Tokalić Rade ${ }^{1}$, Popov Svetlana ${ }^{1}$
}

Received: February 19, 2014

Accepted: March 24, 2014

\begin{abstract}
The possibilities of the application of waste gypsum (citrogypsum, nitrogyosum and sulphogypsum), fly ash and bottom ash in construction: for production of gypsum binders $(\alpha$-calcium sulphate hemihydrate, $\beta$-calcium sulphata hemihydrate and $\beta$-anhydrite), for obtaining construction products (bricks and blocks) and as component materials for road layers were presented in this work. Also, the possibilities of the application of sulphogypsum (or FGD gypsum) for solidification and stabilization of fly ash were presented. The obtained results could have great importance in both ecological and economic views (elimination of important pollutants of water, air and soil, replacement of natural by waste materials, reduction of waste disposal cost).
\end{abstract}

Key words: waste gypsum, fly ash, bottom ash, gypsum binders, construction

\begin{abstract}
Apstrakt: U ovom radu su prikazane mogućnosti primene otpadnog gipsa (citrogipsa, nitrogipsa i sulfogipsa), pepela i šljake u građevinarstvu i to: za proizvodnju gipsnih veziva ( $\alpha$-poluhidrata kalcijum sulfata, $\beta$-poluhidrata calcijum sulfata i $\beta$-anhidrita), za dobijanje gradjevinskih proizvoda (cigala $i$ blokova) i kao materijala za izgradnju gornjih i donjih slojeva puteva. Takođe su prikazane i mogućnosti primene sulfogipsa za solidifikaciju i stabilizaciju pepela. Dobijeni rezultati mogli bi da imaju bitan značaj, kako sa ekološkog gledišta (uklanjanje značajnih zagađivača životne sredine: voda, vazduha i tla) tako i sa ekonomskog gledišta (zamena prirodnih sirovina otpadnim materijalom i smanjenje troškova skladištenja otpadnog materijala).
\end{abstract}

Ključne reči: otpadni gips, pepeo, šljaka, gipsna veziva, građevinarstvo

\footnotetext{
${ }^{1}$ University of Belgrade - Faculty of Mining and Geology, Djušina 7, 11000 Belgrade, Serbia, e-mails: nebojsa.vidanovic@rgf.bg.ac.rs; rade.tokalic@rgf.bg.ac.rs
} 


\section{INTRODUCTION}

\subsection{Gypsum}

Natural gypsum (calcium sulphate dihydrate $-\mathrm{CaSO}_{4} \cdot 2 \mathrm{H}_{2} \mathrm{O}$ ) exists, in general, as alabaster and selenite minerals. Beside natural gypsum, waste or chemical gypsum exists also, and it is nous-product of some technological processes. For example, citrogypsum is nous product of production of citric acid:

$$
\mathrm{Ca}_{3}\left(\mathrm{C}_{6} \mathrm{H}_{5} \mathrm{O}_{7}\right)_{2} \cdot 4 \mathrm{H}_{2} \mathrm{O}+3 \mathrm{H}_{2} \mathrm{SO}_{4}+2 \mathrm{H}_{2} \mathrm{O}=2 \mathrm{C}_{6} \mathrm{H}_{8} \mathrm{O}_{7}+3 \mathrm{CaSO}_{4} \cdot 2 \mathrm{H}_{2} \mathrm{O}
$$
is formed:

By neutralization of acid water during nitrocellulose production nitrogypsum

$$
\mathrm{CaO}+\mathrm{H}_{2} \mathrm{SO}_{4}+\mathrm{H}_{2} \mathrm{O}=\mathrm{CaSO}_{4} \cdot 2 \mathrm{H}_{2} \mathrm{O}
$$

Sulphogypsum (FGD gypsum) is formed in power plants during flue gas desulphurization process:

$$
2 \mathrm{SO}_{2}+2 \mathrm{CaCO}_{3}+4 \mathrm{H}_{2} \mathrm{O}+\mathrm{O}_{2}=2 \mathrm{CaSO}_{4} \cdot 2 \mathrm{H}_{2} \mathrm{O}+2 \mathrm{CO}_{2}
$$

Waste gypsum can replace natural gypsum in different areas, as it is production of gypsum binders. Gypsum binders produce by thermal treatment of gypsum and they are divide in two groups:

1. produced at lower temperatures and

2. produced at higher temperatures.

Gypsum binders produced at lower temperatures are:

$\alpha$-calcium sulphate hemihydrate $\left(\alpha-\mathrm{CaSO}_{4} \cdot 0.5 \mathrm{H}_{2} \mathrm{O}\right)$ and $\beta$-calcium sulphate hemihydrates $\left(\beta-\mathrm{CaSO}_{4} \cdot 0.5 \mathrm{H}_{2} \mathrm{O}\right)$ :

$$
\mathrm{CaSO}_{4} \cdot 2 \mathrm{H}_{2} \mathrm{O}=\mathrm{CaSO}_{4} \cdot 0.5 \mathrm{H}_{2} \mathrm{O}+1.5 \mathrm{H}_{2} \mathrm{O}
$$

The use of hemihydrates is based on their transformation (by addition of optimal water content) in gypsum of good characteristics for practice application:

$$
\mathrm{CaSO}_{4} \cdot 0.5 \mathrm{H}_{2} \mathrm{O}+1.5 \mathrm{H}_{2} \mathrm{O}=\mathrm{CaSO}_{4} \cdot 2 \mathrm{H}_{2} \mathrm{O}
$$

$\alpha-\mathrm{CaSO}_{4} \cdot 0.5 \mathrm{H}_{2} \mathrm{O}$ is produced by "wet process", e.g. by cooking of gypsum in a liquid medium at its temperature of boiling at atmospheric pressure, often in concentrated water salt solutions as $2 \mathrm{M}$ and $3 \mathrm{M} \mathrm{KCl}$ (Marinković et al. 1999) or $2 \mathrm{M}$ and $3 \mathrm{M} \mathrm{LiCl}$ (Marinkovic et al. 2000). This kind of hemihydrate is primary applicable in medicine and stomatology, but also it can be utilized in sculpture and for fine works in construction.

$\beta$-hemihydrate is produced by "dry method", e.g. by gypsum heating at $110^{\circ} \mathrm{C}-130^{\circ} \mathrm{C}$ and atmospheric pressure (in oven). It has an application in construction (as plaster, for decorative elements in architecture, for blocks).

The binders obtained at high temperature are $\beta \mathrm{i} \gamma$ anhydrite $\left(\beta\right.$ - and $\left.\gamma-\mathrm{CaSO}_{4}\right)$, but only $\beta$-form has application in construction ( $\gamma$-form is unstable). $\beta$-anhydrite $\left(\beta-\mathrm{CaSO}_{4}\right)$ is produced by thermal treatment of gypsum at temperature $600^{\circ} \mathrm{C}-700^{\circ} \mathrm{C}$ :

$$
\mathrm{CaSO}_{4} \cdot 2 \mathrm{H}_{2} \mathrm{O}=\mathrm{CaSO}_{4}+2 \mathrm{H}_{2} \mathrm{O}
$$

$\beta$-anhydrite, or anhydrite (II), is insoluble in water and do not react with water, but in the presence of some additives $\left(\mathrm{CaO}, \mathrm{Na}_{2} \mathrm{SO}_{4}, \mathrm{~K}_{2} \mathrm{SO}_{4}\right)$ it reacts with water 
forming calcium sulphate dihydrate, which is called anhydrite cement. Anhydrite cement has application in construction for producing floor and stairs.

\subsection{Fly ash and bottom ash}

Fly ash and bottom ash are solid waste materials from power plants and they present unburnt residue of coal combustion (fly ash present about $80 \%$ and bottom ash about $20 \%$ of this residue). During coal combustion fly ash goes with gas and bottom ash stand out on a bottom of an oven.

Chemical composition of fly and bottom ashes is very complex. They contain organic and inorganic components. Organic components originate from unburned carbon (coal) and inorganic components is composed of amorphous (non-crystalline) part and crystalline part (silicates, hydroxides and oxides, sulphates, sulfides, carbonates, phosphates an so on).

According to classical chemical analysis of fly and bottom ashes (presented by oxides) they are composed of oxides which do not react with water (oxides of $\mathrm{Si}, \mathrm{Al}$, $\mathrm{Fe}$ and $\mathrm{Ti}$ ) and one which react with water (oxides of $\mathrm{Ca}, \mathrm{Mg}, \mathrm{K}, \mathrm{Na}$ and $\mathrm{Ba}$ ).

Besides, some of so called "trace elements" ( $\mathrm{Cu}, \mathrm{Zn}, \mathrm{Cd}, \mathrm{Hg}, \mathrm{As}, \mathrm{Pb}, \mathrm{Sb}, \mathrm{Cr}$ etc.) could be present in the coal ashes in lower but significant concentrations. They are commonly present as impurities in the glass (amorphous) phase and are included in the crystalline components of ashes. Trace elements are mainly enriched in fine-grained fractions of ashes.

Naturally occurring radionuclides: ${ }^{238} \mathrm{U},{ }^{232} \mathrm{Th}$ and ${ }^{40} \mathrm{~K}$ could be also fined in fly and bottom ashes, because they are present in coals.

Flay ash can be classified in two groups (according to American standard ASTM C618 and Canadian standard - Can3-A23.5-M86): class $\mathrm{F}$ with lower $\mathrm{CaO}$ content (lower than 8\%) and higher content of $\mathrm{SiO}_{2}, \mathrm{Al}_{2} \mathrm{O}_{3}$ i $\mathrm{Fe}_{2} \mathrm{O}_{3}$ (higher than 70\%) and class $\mathrm{C}$ with higher $\mathrm{CaO}$ content (higher than 8\%) and lower $\mathrm{SiO}_{2}, \mathrm{Al}_{2} \mathrm{O}_{3}$ i $\mathrm{Fe}_{2} \mathrm{O}_{3}$ (to50 \%).

Fly ash of class $\mathrm{F}$ is composed mainly of aluminosilicates glass and commonly it do not contain a great number of crystalline compounds. Crystalline compounds, which are identified by X-ray diffraction analysis in it, are: quartz - $\mathrm{SiO}_{2}$, mulit $\mathrm{Al}_{6} \mathrm{Si}_{2} \mathrm{O}_{13}$, hematite $-\mathrm{Fe}_{2} \mathrm{O}_{3}$, feldspar - $(\mathrm{Ca}, \mathrm{Na})(\mathrm{Al}, \mathrm{Si})_{4} \mathrm{O}_{8}$ and anhydrite $-\mathrm{CaSO}_{4}$. Fly ash of class $\mathrm{C}$ contains a great number of crystalline compounds of calcium $\left(\mathrm{C}_{3} \mathrm{~A}\right.$ $3 \mathrm{CaO} \cdot \mathrm{Al}_{2} \mathrm{O}_{3}, \mathrm{C}_{4} \mathrm{~A}_{3} \mathrm{~S}-4 \mathrm{CaO} \cdot 3 \mathrm{Al} 2 \mathrm{O} 3 \cdot \mathrm{SiO} 2, \mathrm{CS}-\mathrm{CaO} \cdot \mathrm{SiO}_{2}$ and $\mathrm{CaO}$ ), besaid aluminosilicates glass.

Because of its chemical and mineralogical composition, fly ash of class $\mathrm{C}$ has a property of self-cementing, e.g. it becomes strong by addition of water (without an activator), while fly ash of class $\mathrm{F}$ becomes strong in presence of an activator (lime, gypsum, $\mathrm{NaOH}$ etc.) by addition of water.

Solidification of fly ash is due to hydration reactions which take place between water and silicates and aluminates present in glass phase of fly ash (hydration reactions).On this way hydrated silicates and aluminates form and bind particles of fly ash that improve mechanical properties of material.

Fly ash of class $\mathrm{F}$ became interesting in new days for production of so called FaL-G (fly ash-lime-gypsum) binders. These binders have possible application in 
construction for production of tiles, bricks and blocks and their importance is in connection with reducing of natural source of clay as well as reducing of quantity of waste material (fly ash, sulphogypsum or other waste gypsum) for disposition.

More important for solution of ecological and economic problems of power plant wastes (fly ash, bottom ash and sulphogypsum) disposal is application of these materials for road construction, because road construction need materials in bulk. In usual mix for road construction Portland cement-natural aggregates (sand, gravel, etc.), Portland cement can be replaced (partial or total) by fly ash and sulphogypsum and natural aggregates can be replaced by bottom ash, partial or total. The application of bottom ash as replacement for natural aggregates is in connection with the facts that bottom ash is practically chemical inert and that its constituent particles have size like sand.

The mixtures (with power plant wastes): fly ash-Portland cement-bottom ash and fly ash-sulphogypsum-Portland cement-bottom ash could have potential application in road construction. When water is added to them the reactions of hydration take place, according to:

$$
\begin{aligned}
& 3 \mathrm{CaO}+\mathrm{Al}_{2} \mathrm{O}_{3}+3 \mathrm{CaSO}_{4} \cdot 2 \mathrm{H}_{2} \mathrm{O}+26 \mathrm{H}_{2} \mathrm{O} \rightarrow 3 \mathrm{CaO} \cdot \mathrm{Al}_{2} \mathrm{O}_{3} \cdot 3 \mathrm{CaSO}_{4} \cdot 32 \mathrm{H}_{2} \mathrm{O} \\
& \left(\mathrm{C}_{3} \mathrm{~S}, \mathrm{C}_{2} \mathrm{~S}\right)+\mathrm{H}_{2} \mathrm{O} \rightarrow \mathrm{C}-\mathrm{S}-\mathrm{H}+\mathrm{Ca}(\mathrm{OH})_{2} \cdot\left(\mathrm{C}-\mathrm{S}-\mathrm{H}, \mathrm{C}=\mathrm{CaO}, \mathrm{S}=\mathrm{SiO}_{2}, \mathrm{H}=\mathrm{H}_{2} \mathrm{O}\right)
\end{aligned}
$$

As result of occurrence of these reactions, the solidified material (with mechanical properties available for application in road construction) could be formed.

The usage of waste materials (waste gypsum, fly ash and bottom ash) in construction diminishes the amount of them, but these materials do not use enough. Consequently, a great amount of them is disposed in a landfill and represent potential pollutants for environment (air, water, soil). In new days in many developed countries of Europe the safe deposition of wastes is controlled by lows, in aim to protect human life environment. Solidification/stabilization technology is such new way for safe disposal of wastes from power plants (fly ash, bottom ash and flue gas desulphurisation gypsum). In this technology the wastes are transformed (by adding of water and necessary additives) into stable-solidified state in which hazardous substances (heavy metals and so on) are inhibited to arrive in environment (air, water, soil).

\subsection{Examination the possibility of application of waste gypsum, fly ash and bottom ash}

To solve the problems of waste materials in Serbia, the possibilities of usage of waste materials from Serbian factories in construction were investigated, for a long time. These materials were:

- $\quad$ waste gypsum: citrogypsum (from citric acid factory - Ćuprija, existing in this time ) and nitrogypsum (from nitrocellulose factory "Milan Blagojević" - Lučani) and

- $\quad$ power plant solid wastes: fly ash and bottom ash (from "Nikola Tesla" power plant - Obrenovac).

Sulphogypsum, the tird solid waste from power plants, do not produce in power plants of Serbia, because in these factories do not use contemporary method of desulphurization of flu gases. This method will be applied soon in "Nikola Tesla" 
power plant, and a new waste material-sulphogypsum (FGD gypsum) shall appear. Because of that, the possibility of usage in construction sulphogypsum from power plant Hvaletice-Bohemia was investigated.

The results of the investigations were obtained during elaboration of the following subjects supported by Ministry of the Science of Seria:

- Obtaining of inorganic binders from natural and secondary ores (period 19911995 years);

- Mechanism and kinetics of obtaining inorganic binders from natural and secondary ores (period 1996-2000 years);

- Utilization of environmental pollutants, flay ash and waste gypsum, as ores for obtaining of useful products (period 2001-2004 years);

- Investigation of applicability of power plant waste materials: fly ash and bottom ash in construction (period 2005-2007 years);

- Investigation of possibility of utilization of flay ash, bottom ash and flue gas desulphurization gypsum for road construction (period 2008-2010 years).

The obtained resultants pointed to the possibility of the usage of studied waste materials in following areas:

1. Production of gypsum binders $(\alpha$-calcium sulphate hemihydrate, $\beta$-calcium sulphate hemihydrate and $\beta$-anhydrite);

2. Obtaining of construction products (bricks and blocks);

3. Utilization as component materials for production of road layers.

Also, the examination of flue gas desulphurization gypsum applicability for solidification/stabilisation of fly ash from "Nikola Tesla" power plant gave good results (Marinković et al. 2004a; 2006a).

\section{EXPERIMENTAL, RESULT AND DISCUSSION}

The following classic and modern instrumental analyses were used for investigation of properties of waste materials (citrogypsum, nitrogypsum, sulphogypsum, fly ash and bottom ash); products obtained from these materials (gypsum binders and FaL-G binder) and mixtures of materials (fly ash-Portland cement-bottom ash-water and fly ash-sulphogypsum-Portland cement-bottom ashwater):

- Classic quantitative chemical analysis for determination of chemical composition;

- Classic analyses for determination of physic and mechanical properties;

- Gamma spectrometric analysis for determination of specific activity of radioactive nuclides;

- Atomic absorption spectrophotometric method for determination of concentration of trace elements;

- $\quad$ X-ray diffraction analysis (XRD) for determination of mineralogical composition;

- Qualitative infra-red analysis (IR-analysis) for qualitative determination of composition;

- differential thermal analysis and thermogravimetric analysis (DTA/TG) for qualitative and quantitative determination of composition. 
On the basis of the examination of waste gypsums (citrogypsum, nitrogypsum and sulphogypsum) by classic chemical analysis, X-ray diffraction analysis (XRD), qualitative infra-red analysis (IR-analysis) and differential thermal analysis (DTA), it was concluded that these materials presented calcium sulphate dihydrate $\left(\mathrm{CaSO}_{4} \cdot 2 \mathrm{H}_{2} \mathrm{O}\right)$ with lower content of impurities: nitrates and carbonates in nitrogypsum and carbonates in sulphogypsum.

Consequently, the possibilities of applicability of these materials in construction were investigated with raw materials (citrogypsum, nitrogypsum and sulphogypsum) and with materials (citrogypsum and sulphogypsum) from which impurities were separated by $\mathrm{H}_{2} \mathrm{SO}_{4}$.

On the basis of classic chemical analysis (oxides analysis) and X-ray diffraction analysis (XRD) of fly ash from "Nikola Tesla" power plant it was established that it belonged to class $\mathrm{F}$ (according to ASTM). This material has low content of $\mathrm{CaO}$ (lower than 8\%), high content of $\mathrm{SiO}_{2}, \mathrm{Al}_{2} \mathrm{O}_{3}$ and $\mathrm{Fe}_{2} \mathrm{O}_{3}$ (higher than $70 \%$ ) and low content of unburnt carbon (coal). The crystalline phase in it consisted of minerals: quartz $\left(\mathrm{SiO}_{2}\right)$, mulite $\left(\mathrm{Al}_{6} \mathrm{Si}_{2} \mathrm{O}_{13}\right)$, anhydrite $\left(\mathrm{CaSO}_{4}\right)$, feldspar $\left(\mathrm{NaAlSi}_{3} \mathrm{O}_{8}\right)$, diopside $\left(\mathrm{CaMg}\left(\mathrm{SiO}_{3}\right)_{2}\right)$ and hematite $\left(\mathrm{Fe}_{2} \mathrm{O}_{3}\right)$. In addition to crystalline phase, a significant amount of amorphous phase (chemical active amorphous aluminosilicates) was established in examined fly ash. By granulometric analysis of fly ash (sieving through Taylor sieve) it was stated that it presented powdered material $(90 \%$ particles with size lower than $0.6 \mathrm{~mm}$ ). The results of chemical, X-ray diffraction and granulometric analysis showed a good chemical activity of fly ash from "Nikola Tesla" power plant and possibility of its utilization in construction as replacement for Portland cement.

The investigation of the content of radioactive nuclides and heavy metals in fly and bottom ashes from "Nikola Tesla" power plant-Obrenovac showed that the content of radioactive nuclides in them do not exited permissible limits (according to SRPS 8/87), but the content of heavy metals $\mathrm{Cd}$, $\mathrm{Ni}$ and $\mathrm{Pb}$ was above permissible limits (according to Germane and Italian lows for safe disposal of fly and bottom ashes; Serbian low do not exist) (Marinkovic et al. 2010a). These results were shown that fly and bottom ashes from "Nikola Tesla" power plant presented potential pollutants for natural waters near power plant station. Because of that, it is need to delay these materials by new solidification/stabilization method (Marinković et al. 2004a; 2006a), which is not applied now in "Nikola Tesla" power plant.

By classical chemical analysis and X-ray diffraction analysis of bottom ash from power plant "Nikola Tesla", it was established that this material had lower content of $\mathrm{SiO}_{2}, \mathrm{Al}_{2} \mathrm{O}_{3} \mathrm{i} \mathrm{Fe}_{2} \mathrm{O}_{3}$ and lower content of amorphous substances than fly ash. In that way bottom ash is a relative inert substance, which is convenient for an application as aggregate in mixtures of materials for road construction. However, the determination of physical properties of bottom ash showed that it had some inconvenient properties for application as aggregate: low density, low bulk density and low maximum dry density (compaction). These low physical properties could be related with high content of unburnt carbon in bottom ash (bottom ash from "Nikola Tesla" power plant contain variable but always high content of unburnt carbon-coal, higher than permissible values by ASTM). 
On the basis of before suggested examinations of properties of waste materials (waste gypsum from citric acid factory-Ćuprija, waste gypsum from nitrocellulose factory-Lučani, waste gypsum from thermo power station-Hvaletice, Bohemia, as well as fly and bottom ashes from "Nikola Tesla" power plant) it was concluded that these materials had enough good properties for investigations about their applicability for construction. These investigations included raw materials and treated materials: nitrogypsum and sulphogypsum treated by $\mathrm{H}_{2} \mathrm{SO}_{4}$ for elimination of impurities, as well as bottom ash treated by saving or by the "float-sink" method for diminishing unburnt carbon content. The following possibilities were examined:

1. Obtaining of $\alpha$-calcium sulphate hemyhidrate from waste gypsum;

2. Obtaining of $\beta$-calcium sulphate hemihydrate from waste gypsum;

3. Obtaining of $\beta$-anhydrite from waste gypsum;

4. Obtaining of fly ash-lime-gypsum (FaL-G) binder from waste gypsum and fly ash;

5. Utilization of waste materials from power plant station: fly ash, bottom ash and sulphogypsum as components in material mixtures for road construction.

\subsection{Obtaining of $\alpha$-calcium sulphate hemyhidrate $\left(\alpha-\mathrm{CaSO}_{4} \cdot 0.5 \mathrm{H}_{2} \mathrm{O}\right)$ from waste gypsum}

The investigations of the possibilitiy of obtaining of $\alpha$-calcium sulphate hemyhidrate $\left(\alpha-\mathrm{CaSO}_{4} \cdot 0.5 \mathrm{H}_{2} \mathrm{O}\right)$ were performed by treatment of waste gypsum (citrogypsum and sulphogypsum or FGD gypsum) in different liquid media (KostićPulek et al. 1995; 1996; 2000; 2005).

On the basis of these investigations it was concluded that $\alpha-\mathrm{CaSO}_{4} \cdot 0.5 \mathrm{H}_{2} \mathrm{O}$ could be obtained from citrogypsum in boiling $3 \mathrm{M} \mathrm{MgCl}_{2}$ (at atmospheric pressure) (Kostić-Pulek et al. 1995) and in $\mathrm{H}_{2} \mathrm{SO}_{4}$ solution of different concentration $(10,20,30$, and 40 mass \% solution) at ambient temperature and atmospheric pressure (KostićPulek et al. 2000). Also, $\alpha$-CaSO ${ }_{4} \cdot 0.5 \mathrm{H}_{2} \mathrm{O}$ was obtained from sulphogypsumin in $3 \mathrm{M}$ $\mathrm{NaCl}$ solution (at temperature of boiling and atmospheric pressure) (Kostić-Pulek et al. 1996). By treatment of sulphogypsum in $20 \% \mathrm{H}_{2} \mathrm{SO}_{4}$ solution (at ambient conditions) the mixture of $\alpha-\mathrm{CaSO}_{4} \cdot 0.5 \mathrm{H}_{2} \mathrm{O}$ and $\beta-\mathrm{CaSO}_{4} \cdot 0.5 \mathrm{H}_{2} \mathrm{O}$ was formed (Kostić-Pulek et al. 2005).

\subsection{Obtaining of $\beta$-calcium sulphate hemihydrate from waste gypsum}

The investigations of the possibilitiy of obtaining of $\beta$-calcium sulphate hemyhidrate $\left(\beta-\mathrm{CaSO}_{4} \cdot 0.5 \mathrm{H}_{2} \mathrm{O}\right)$ were performed by heating waste gypsum (nitrogypsum and sulphogypsum) in open oven at $130^{\circ} \mathrm{C}$ (Marinković et al. 2002; 2005a). The investigation were included raw waste gypsum and waste gypsum treated with $\mathrm{H}_{2} \mathrm{SO}_{4}$ solution for elimination of impurities (nitrate and carbonate from nitrogypsum and carbonates from sulphogypsum).

It was concluded that $\beta$-calcium sulphate hemyhidrate was obtained from both kind of raw and treated waste gypsum. By mixing $\beta$-calcium sulphate hemyhidrate 
with water calcium sulphate dehydrate $-\mathrm{CaSO}_{4} \cdot 2 \mathrm{H}_{2} \mathrm{O}$ was formed. The formed $\mathrm{CaSO}_{4} \cdot 2 \mathrm{H}_{2} \mathrm{O}$ had available properties for application in construction (plaster), especially if it was obtained by mixing $\beta$-calcium sulphate hemyhidrate from treated gypsum and water.

\subsection{Obtaining of $\beta$-anhydrite ( $\beta$-calcium sulphate) or anhydrite (II) from waste gypsum}

The possibilities of obtaining $\beta$-anhydrite $\left(\beta-\mathrm{CaSO}_{4}\right)$ or anhydrite (II) from waste gypsum (citrogypsum and nitrogypsum) were investigated by heating these materials at high temperature $\left(600^{\circ} \mathrm{C}\right.$ and $\left.700^{\circ} \mathrm{C}\right)$ in kiln at atmospheric pressure.

On the bases of the obtained results it was concluded that $\beta$-anhydrite $\left(\beta-\mathrm{CaSO}_{4}\right)$ could be produced by heating citrogypsum at temperature $700^{\circ} \mathrm{C}$ (Marinković et al. 2001) and $600^{\circ} \mathrm{C}$ (Marinković et al. 1998). The obtained $\beta$-anhydrite reacted with water (reaction of hydration) and solidified in presence of $1.5 \% \mathrm{Na}_{2} \mathrm{SO}_{4}$ (Marinković et al. 2001) and $1.7 \% \mathrm{Na}_{2} \mathrm{SO}_{4}$ (Marinković et al. 1998). The solidified material or anhydrite cement had available properties for application in construction.

By heating of nitrogypsum at $700^{\circ} \mathrm{C}, \beta$-anhydrite was obtained also. This material solidified in presence of water and 2 mass $\% \mathrm{Na}_{2} \mathrm{SO}_{4}$ or 2 mass $\% \mathrm{~K}_{2} \mathrm{SO}_{4}$ (additives) (Marinković et al. 2003a; 2004b). The solidified material - anhydrite cement had convenient properties for use in construction.

\subsection{Obtaining of fly ash-lime-gypsum (FaL-G) binder from waste gypsum and fly ash}

The possibilities of obtaining of FaL-G binder were investigated by mixing the mixture: fly ash, lime and calcined FGD gypsum ( $\beta$-calcium sulphate hemihydrate produced by heating of FGD gypsum at $130^{\circ} \mathrm{C}$ ) with water.

The results showed that the mixture fly ash-lime-calcined FGD gypsum $=2: 1: 2$ behaved as binder (FaL-G binder) in presence of water. The hydration reactions which took place in the system fly ash-lime-calcined FGD gypsum-water made material with properties convenient, according to Serbian standard, for manufacture of wall materials (brick and blocks) (Marinković et al. 2003b; 2004c; Marinkovic and Kostic-Pulek, 2007).

Also, it was established that the mixture fly ash-lime-calcined FGD gypsum $=7: 1: 2$ formed compact product with water, which had adequate properties for potential use in production of building products (bricks and blocks), according to Serbian standard (Marinkovic et al. 2005b).

However, the results of investigations were pointed to the presence of important amount of gypsum in the products formed in both system fly ash-limecalcined FGD gypsum-water (Marinković et al. 2003b; 2004c; 2005b; Marinkovic and Kostic-Pulek, 2007). The presence of gypsum, because of its relatively solubility in water, reduces the use of the mentioned mixtures to the manufacture of internal wall materials (bricks and blocks). 


\subsection{Application of waste materials from power plants: fly ash bottom ash and sulphogypum (FGD gypsum) as materials for road construction}

In aim to investigate the possibilities of utilization of waste materials from power plants as materials for road construction the following mixtures were made:

1. Fly ash-Portland cement-bottom ash;

2. Fly ash-Portland cement-bottom ash-sand;

3. Fly ash-Portland cement-FGD gypsum-bottom ash and

4. Fly ash-Portland cement-FGD gypsum-bottom ash-sand.

These mixtures of different composition were mixed with water under pressure (Proctor specimens) and so prepared specimens were investigated for their properties (physical and mechanical) and composition. It was utilized bottom ash without any treatment (raw bottom ash) and bottom ash which was sieved from separation of coarse particles with high content of unburnt carbon, or treated bottom ash by the "float-sink" method (to separate more light particles of unburnt carbon).

\subsubsection{Mixtures: fly ash-Portland cement-bottom ash and fly ash-Portland cement-bottom ash-sand}

The results of examination were shown that the mixtures fly ash-Portland cement-bottom ash $(3: 1: 4,4: 1: 5$ and $3: 1: 6)$, which contained raw bottom ash, could be applied only for sub-base road layers (Marinković et al. 2006b; 2007; 2008a; 2008b; 2009; 2010b; 2011a; Trifunović et al. 2010). On the other side, when bottom ash with lower content of unburnt carbon (bottom ash sawed or treated by "float-sink" method) was used, the mixture fly ash-Portland cement-bottom ash $(3: 1: 4)$ could be applied both for sub-base and base road layers (Marinković et al. 2006b; 2008a).

The examinations of the mixtures fly ash-Portland cement-bottom ash-sand $(3.75: 1.25: 4: 1 ; 3: 1: 2.4: 1.6$ and $3: 1: 2: 2)$ were established the positive role of the presence of sand. Namely, these mixtures could be utilized both for sub-base and base road layers (Marinković et al. 2008a).

\subsubsection{Mixtures: fly ash-Portland cement-FGD gypsum-bottom ash and fly ash-Portland cement-FGD gypsum-bottom ash-sand}

The results of examinations of the mixture which (beside fly ash, Portland cement and bottom ash) contain FGD gypsum showed that the presence of FGD gypsum in the mixture (fly ash- Portland cement-FGD gypsum-bottom ash $=3: 1: 1: 5$ ) leaded to carbonation phenomenon (Tokalic et al. 2013).

Namely, it was stated (by means of X-ray diffraction analysis) that ettringite (obtained by the reactions between FGD gypsum and calcium aluminates from Portland cement and fly ash), reacted with $\mathrm{CO}_{2}$ from air according to:

$3 \mathrm{CaO} \cdot \mathrm{Al}_{2} \mathrm{O}_{3} \cdot 3 \mathrm{CaSO}_{4} \cdot 32 \mathrm{H}_{2} \mathrm{O} \cdot 3 \mathrm{CO}_{2}=3 \mathrm{CaCO}_{3}+3 \mathrm{CaSO}_{4} \cdot 2 \mathrm{H}_{2} \mathrm{O}+\mathrm{Al}_{2} \mathrm{O}_{3} \cdot \mathrm{nH}_{2} \mathrm{O}+(26-\mathrm{n}) \mathrm{H}_{2} \mathrm{O}$

The formation of gypsum during reaction, e.g. the presence of gypsum in solidified material limits its utilization for road construction, because of gypsum 
solubility in water. By dissolution of gypsum in water $\mathrm{SO}_{4}{ }^{2-}$ ions appear and so called "internal sulphate attack" can occur, which can cause breaking of material.

In aim to minimize carbonation phenomenon bottom ash was partially substituted by sand (the mixture fly ash-Portland cement-FGD gypsum-bottom ashsand $=3: 1: 1: 4: 1$ ). The obtained results (Marinković et al. 2011b) were shown positive effect of the presence of sand (sand is not porous material and its presence diminishes $\mathrm{CO}_{2}$ diffusion and carbonation phenomenon).

\section{CONCLUSION}

The presented results which relate to the usage of waste materials from Serbia (gypsum, fly ash and bottom ash) were obtained on laboratory level. They pointed that mentioned materials could have a potential application in construction: for production gypsum binders, for obtaining construction products and as materials for road construction. The application of these results in practice could have a great importance for our country in area of recycling of waste materials. The recycling of waste materials attracts great attention in all developed countries, both in ecological and economic views. In our country recycling of waste materials is not so developed, because many appropriate regulations, standards and lows about application of waste materials in construction are missing. A wide field of investigations and real results for practice related with recycling of waste materials, could be realize by establishing of these regulations, standards and lows. On that way recycling of waste materials could have more important role in present and future time.

\section{REFERENCES}

[1] KOSTIĆ-PULEK, A. et al. (1995) The use of citrogypsum in high grade calcium sulphate alpha-hemihydrate production by hydrothermal method. In: Proceeding of the Fourth European Ceramic Society Conference (Volume 1), Riccione, October 1995. Faenza: Gruppo Editoriale Faenza Editrice, pp.173178.

[2] KOSTIĆ-PULEK, A. et al. (1996) Developing a hydrothermal technique for production of alpha-hemihydrate calcium sulfate from flue gas gypsum. Ceramics-Silicaty, 40, pp.99-102.

[3] KOSTIĆ-PULEK, A. et al. (2000) Production of calcium sulphate alphahemihydrate from citrogypsum in unheated sulphuric acid solution. CeramicsSilicaty, 44, pp.104-108.

[4] KOSTIĆ-PULEK, A. et al. (2005) The treatment of gypsum as a product of the flue desulphurization process, Ceramics-Silikaty, 49, pp.115-119.

[5] MARINKOVIĆ, S. et al. (1998) Comparative properties study of anhydrite (II) prepared from natural and waste gypsums. Physicochecal Problems of Mineral Processing, 32, pp.95-108.

[6] MARINKOVIĆ, S. et al. (1999) Products of Hydrothermal Treatment of Selenite in Potassium Chloride Solutions. Journal of Thermal Analysis and Calorimetry, 57, pp.559-567. 
[7] MARINKOVIC, S. et al. (2000) The products of selenite hydrothermal treatment in lithium chloride solutions, J. Serb. Chem. Soc., 65, pp.265-274.

[8] MARINKOVIĆ, S. et al. (2001) Properties study of anhydrite (II) prepared from natural and waste gypsum. In: Proceedings of the International Conference "New Trends in Mineral Procesing IV", Ostrava, June 2001. Ostrava: Mining University of Ostrava, pp.87-94.

[9] MARINKOVIĆ, S. et al. (2002) The possibility of obtaining $\beta$-calcium sulphate hemihydrate from waste nitrogypsum. Tile and Brick International, 18, pp.374-377.

[10] MARINKOVIĆ, S. et al. (2003) The possibility of obtaining beta-anhydrite from waste nitrogypsum. In: Proceedings of the 30th International Conference of Slovak Society of Chemical Engineering, Tatranske Matliare, May 2003. Bratislava: Slovak Society of Chemical Engineering, CD Proceedings 1-7.

[11] MARINKOVIĆ, S. et al. (2003) The possibilities of fly ash and FGD gypsum utilization in manufacturing of building products. Tile and Brick, 19, pp.398-404.

[12] MARINKOVIĆ, S. et al. (2004) The reactivity of fly ash of interest for its solidification. In: Proceedings of the 7th International Conference on Fundamental and Applied Aspects of Physical Chemistry (Volume II), Belgrade, Septembre 2004. Belgrade: The Society of Phisical Chemists of Serbia, pp.685-687.

[13] MARINKOVIĆ, S. et al. (2004) The possibility ofobtaining beta-anhydrite from waste nitrogypsum. Journal of Mining and Metalurgy, 40B, pp.89-100.

[14] MARINKOVIĆ, S. et al. (2004) Fly ash and FGD gypsum as raw materials for the manufacture of building products. In: Proceedings of the 31th International Conference of Slovak Society of Chemical Engineering, Tatranske Matliare, May 2004. Bratislava: Slovak Society of Chemical Engineering, CD Proceedings 1-9.

[15] MARINKOVIC, S. et al. (2005) Recycling of waste FGD gypsum. In: Proceedings of the 32th International Conference of Slovak Society of Chemical Engineering, Tatranske Matliare, May 2005. Bratislava: Slovak Society of Chemical Engineering, CD Proceedings 1-9.

[16] MARINKOVIC, S. et al. (2005) The reactivity of fly ash of interest for the manufacture of building materials. Interceram, 54, pp.32-36.

[17] MARINKOVIĆ, S. et al. (2006) Solidification/Stabilization of Power Plants Wastes - Potential Water Pollutants. In: Proceedings of the Second Conference on Water observation and information system for decision support BALWOIS 2006, Ohrid 2006. Skopje: Hydrometeorological Service of Republic of Macedonia, CD Proceedings 1-8.

[18] MARINKOVIĆ, S. et al. (2006) Assesment of coal combustion by-products for road construction. In: Proceedings of the "Power Plants 2006", Vrnjačka Banja, May 2006. Belgrade: The Society of Thermal Engineers of Serbia, CD Proceedings 1-9.

[19] MARINKOVIC, S. and KOSTIC-PULEK, A. (2007) Examination of the system fly ash-lime calcined gypsum-water. Journal of Physics and Chemistry of Solids, 68, pp.1121-1125. 
[20] MARINKOVIC, S. et al. (2007) Pre-treatment of bottom ash for useful application in road construction. In: Proceedings of the 34th International Conference of Slovak Society of Chemical Engineering, Tatranske Matliare, May 2007. Bratislava: Slovak Society of Chemical Engineering, CD Proceedings 1-7.

[21] MARINKOVIĆ, S. et al. (2008) Recycling of power plants wastes- potential water pollutants. In: Proceedings of the Third Conference on Water observation and information system for decision support BALWOIS 2008, Ohrid, May 2008. Skopje: Faculty of civil engineering, CD Proceedings 1-9.

[22] MARINKOVIĆ, S. et al. (2008) Investigation on the possibilities of the application of fly ash from "Nikola Tesla" power plants - Obrenovac for road construction. In: Proceedings of the "Power Plants 2008", Vrnjačka Banja, October 2008. Belgrade: The Society of Thermal Engineers of Serbia, CD Proceedungs 1-7.

[23] MARINKOVIĆ, S. et al. (2009) DTA/TGA studies of bottom ash from the "Nikola Tesla" power plant from Serbia for the purpose of its utilization in road construction. In: Proceedings of the 36th International Conference of Slovak Society of Chemical Engineering, Tatranske Matriale, May 2009. Bratislava: Slovak Society of Chemical Engineering, CD Proceedings 1-7.

[24] MARINKOVIC, S. et al. (2010) Evalution of potential pollution of natural water by trace elements originating from power plant ashes. In: Proceedings of the 4th Conference on Water observation and information system for decision support BALWOIS 2010, Ohrid, May 2010. Skopje: Faculty of civil engineering, $C D$ Proceeding 1-5.

[25] MARINKOVIĆ, S. et al. (2010) Recycling of power plant wastes for road construction. In: Proceedings of the 42th International October Conference on Mining and Metallurgy, Kladovo, October 2010. Bor: University of Belgrade - Technical Faculty in Bor; Mining and Metallurgy Institute Bor, pp.436-439.

[26] MARINKOVIĆ, S. et al. (2011) Recycling of coal ashes from Serbian "Nikola Tesla" power plant. In: Proceedings of the 43th International October Conference on Mining and Metallurgy, Kladovo, October 2011. Bor: University of Belgrade - Technical Faculty in Bor; Mining and Metallurgy Institute Bor, pp.55-58.

[27] MARINKOVIĆ, S. et al. (2011) Applicability of wastes from power plant as road materials. In: Book of Abstracts of the Third Regional Conference Industrial Energy and Enviromental Protection in Southeastern Europe, Kopaonik, June 2011. Belgrade: The Society of Thermal Engineers of Serbia, Book of Abstracts 41.

[28] TOKALIC, R. et al. (2013) Preliminary Examination of the System Fly AshBottom Ash-Flue Gas Desulphurization Gypsum-Portland Cement-Water for Road Construction. Journal of Chemistry, 2013, pp.1-7.

[29] TRIFUNOVIĆ, P. et al. (2010) The effect of the content of unburned carbon in bottom ash on its applicability for road construction. Thermochimica Acta, 498, pp.1-6. 